Communication

\title{
New Heights of the Highest Peaks of Polish Mountain Ranges
}

\author{
Krystian Kozioł (1) and Kamil Maciuk *(1) \\ Faculty of Mining Surveying and Environmental Engineering, AGH University of Science and Technology, \\ Al. Mickiewicza 30, 30-059 Krakow, Poland; krystian.koziol@agh.edu.pl \\ * Correspondence: maciuk@agh.edu.pl; Tel.: +48-12-617-22-59
}

Received: 8 April 2020; Accepted: 29 April 2020; Published: 2 May 2020; Corrected: 22 April 2022

\begin{abstract}
The idea to verify the height of the highest peaks (summits) in the Crown of Polish Mountains arose after analyzing sources regarding the date and method of measuring the height of these mountain peaks. Our investigations revealed that this type of material is not usually available, and the first mention of height values is most often noted in the inter-war period, and occasionally before WWI (when Poland did not exist as an independent state); most of these values are still in use to this day. The problem of accurate measurement of the height of mountain peaks concerns not only the peaks analyzed by the authors, but also almost all mountain peaks worldwide. Therefore, as part of this work, several trips were organized to the highest peaks of several dozen mountain ranges in the territory of Poland. Measurement was made using a precise geodetic GNSS receiver an accuracy of within $10 \mathrm{~cm}$ and a DTM model based on ALS (airborne laser scanning). The results showed that commonly published heights can differ by up to several meters from the actual ones. The most important element of this work consists of the establishment of new measurements of the heights of the highest peaks of all mountain ranges in Poland, which may result in an alteration of the officially recorded heights based on this article. Apart from verification of these heights, this work also aimed to address the issue of the heights of all characteristic objects whose heights must be verified by using modern satellite techniques.
\end{abstract}

Keywords: GNSS; height verification; mountain; peak; RTK; summit

\section{Introduction}

The Crown of Polish Mountains (CPM) is a list of the 28 highest peaks of the main mountain ranges (mesoregions) in Poland (Figure 1). The concept of CPM was established in 1997 [1]. Currently, the CPM club, a club bringing together Polish mountain enthusiasts, has over 40,000 members including over 2000 members who have summited all the 28 peaks listed (https://kgp.info.pl/). The idea of verification of the height of the peaks included in the CPM list arose after verification of the height of two of the highest summits in Ukraine-the Hoverla and Pop Ivan peaks, where inaccuracies of up to several meters were also found [2]. In addition, the analysis of available cartographic materials confirmed numerous inconsistencies related to the heights of mountain peaks.

Although the highest peaks of each range are frequently visited as mountain tourism destinations (e.g., Tarnica, Śnieżka or Babia Góra), in numerous materials we analyzed, including historical maps, current maps and guidebooks, and the Internet, significant discrepancies appeared, amounting to as much as several meters. Figure 2 illustrates how the published height of Babia Góra has changed since the beginning of the $19^{\text {th }}$ century. The current height of this summit is listed as $1725 \mathrm{~m}$ a.s.l (above sea level). All heights in the article are shown in meters above sea level. 


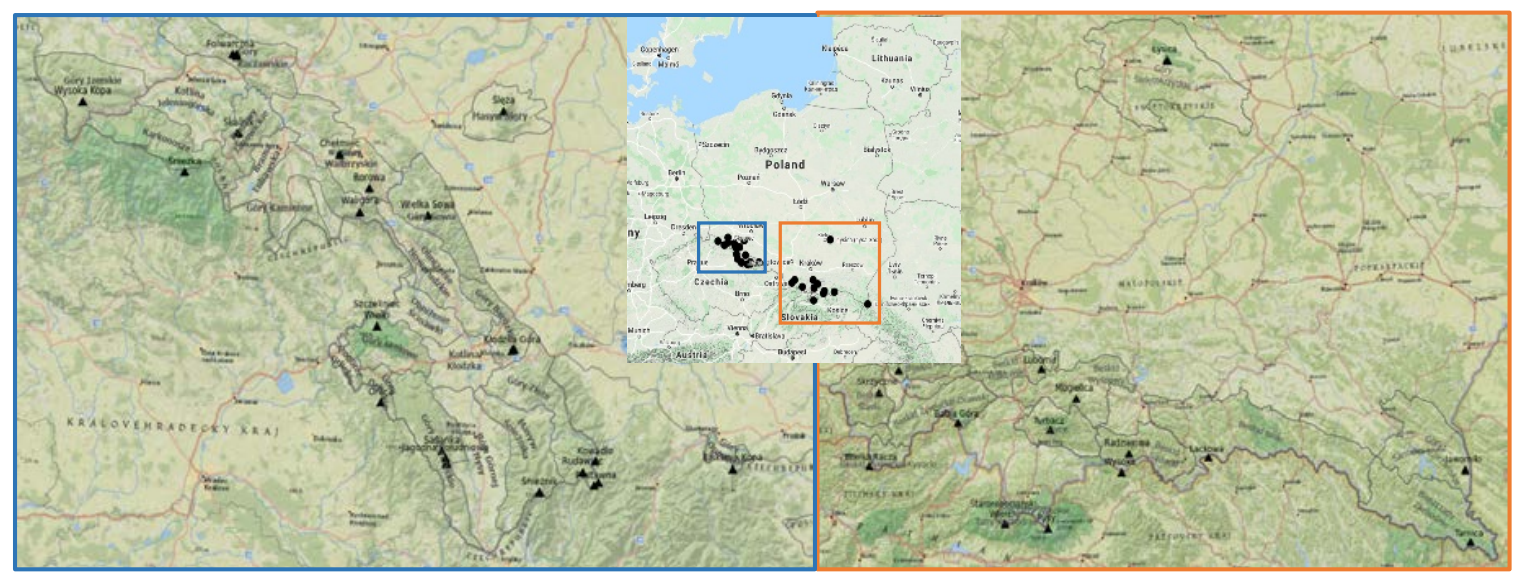

Figure 1. Distribution of the Crown of Polish Mountains (CPM) summits.

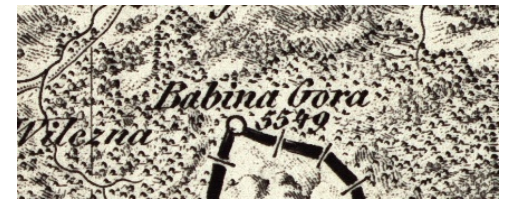

$1754^{+} \mathrm{m}\left(1824^{1}\right)$

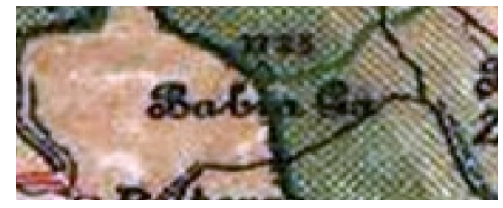

$1723 \mathrm{~m}\left(1926^{1}\right)$

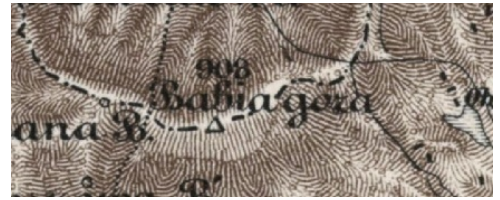

$1722^{\ddagger} \mathrm{m}\left(1880^{1}\right)$

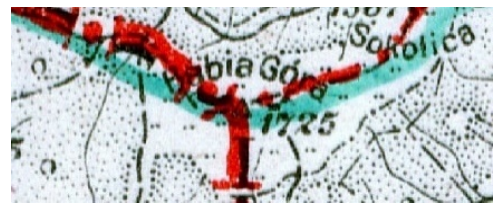

$1725 \mathrm{~m} \mathrm{(1937^{1 } )}$

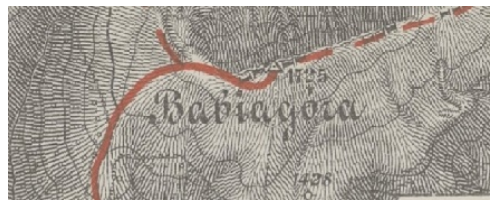

$1725 \mathrm{~m}\left(1896^{2}\right)$

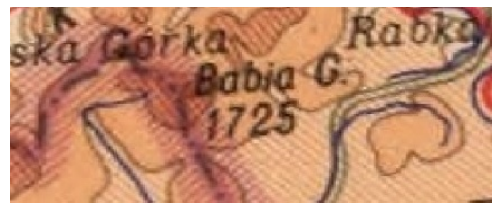

$1725 \mathrm{~m}\left(1967^{3}\right)$

Figure 2. Changes in the published height of the Babia Góra summit over the years, since 1824. Source: ${ }^{1}$ http://www.mapywig.org/, ${ }^{2}$ https://polona.pl/, ${ }^{3}$ https://www.davidrumsey.com/, ${ }^{\dagger}$ Vienna foot $=0.3161 \mathrm{~m} \mathrm{[3],} \mathrm{\ddagger} \mathrm{Vienna} \mathrm{fathom}=1.8966 \mathrm{~m} \mathrm{[3].}$

In addition, there is a lack of research in this area, especially for little-known and rarely frequented summits. As studies of the literature have shown, the most iconic and globally recognized peaks have already been thoroughly tested using same the GNSS technique that we used, such as Mount Everest [4-6], Mont Blanc [7], Aconcagua [8] or Kilimanjaro [9,10]. Polish summits have also been measured in this way, but to a very limited extent; the only measurements conducted with geodetic receivers were of the peaks of Rysy [11] and Śnieżka (http://www.krkonose.eu/pl/aktuality/813/).

Therefore, in 2019 a project which was named 'Setka w Koronie. Korona Gór Polski na 100-lecie AGH' (100 in the Crown: The Crown of Polish Mountains on the 100-year anniversary of AGH University of Science and Technology in Kraków) was initiated. The aim of this project was the measurement and verification of the height of the highest peaks of individual mountain ranges in Poland using modern satellite measurement techniques.

\section{Materials and Methods}

\subsection{Preparatory Work}

The project was implemented from May to December 2019. The objects of study were the 28 highest points on the CPM list. Based on the analysis of source materials, such as the DEM (digital elevation model), mountain forums, maps and guidebooks, as well as other sources, a list of potential peaks for height verification was determined. About 20 people participated in the measurements; a single measurement team usually consisted of 5-7 people, and more than 30 measurement expeditions were carried out in this way. The characteristics of the selected ranges and peaks had a huge impact on the 
course of the measurements. Some of the summits are located within national parks, which required the researchers to obtain the appropriate permits. During the implementation of the works, peaks believed to be potentially higher than their listed heights were identified. Ultimately (although there are only 28 peaks officially listed in the CPM), our measuring team verified the heights of 39 peaks. Techniques ensuring accuracy to within $10 \mathrm{~cm}$, such as LIDAR (light detection and ranging) [12] or drone measurements [13], may provide the required accuracy, however, these techniques are susceptible to distortions due to resolution, weather conditions or plant cover. InSAR (synthetic aperture radar interferometry) is very accurate for testing relative height changes, though in the case of determining absolute values, it provides an accuracy only to within 1-2 $\mathrm{m}$ [14]. Therefore, it was decided to conduct direct GNSS measurements in the field, using LIDAR data to determine the 2D position of the points considered to potentially be the highest and to determine their values. The highest points at the top of each peak were identified based on DEM analyses and data from aerial laser scanning obtained as part of the ISOK project (https://www.isok.gov.pl/). Figure 3 shows data and the workflow for a single peak analysis.

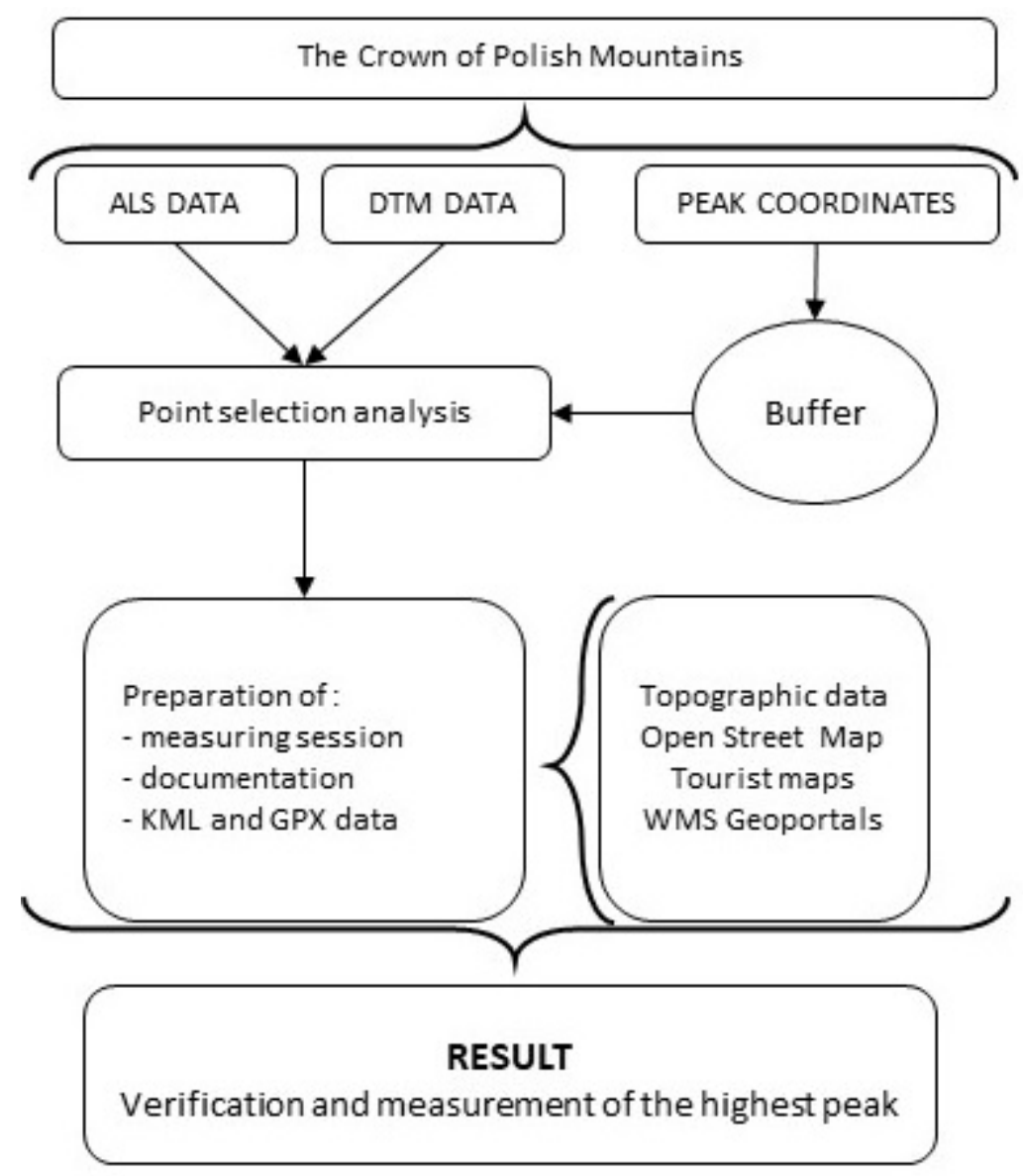

Figure 3. Diagram showing the data and the workflow for a single peak analysis.

An example of such analysis and direct measurement in the field is shown in Figure 4. Subsequently, we verified these data in the field during measurement. 


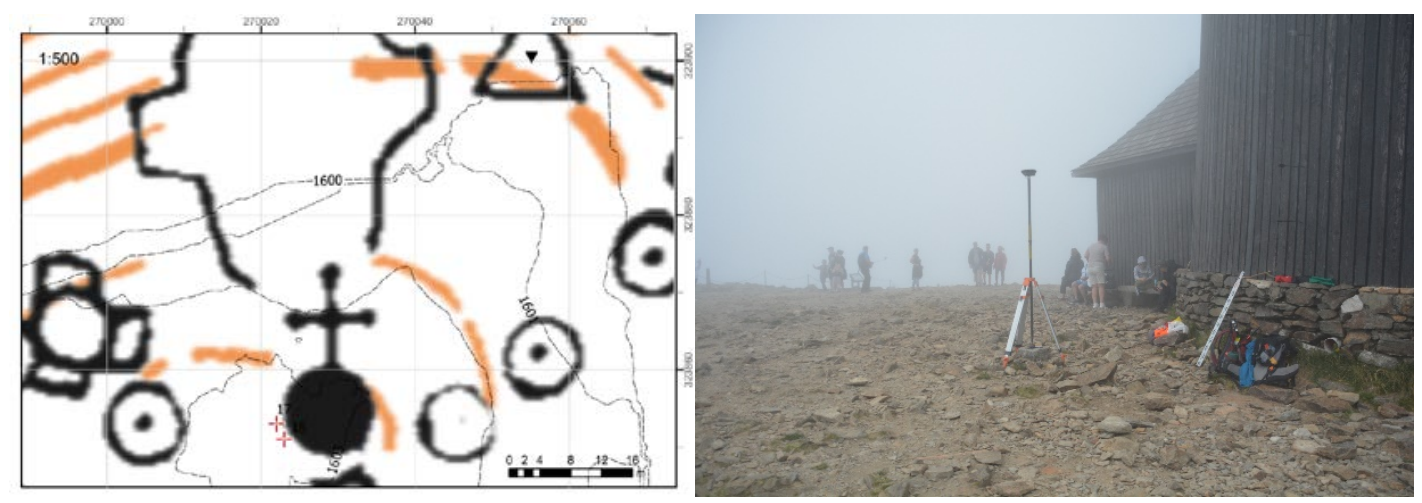

Figure 4. Points potentially considered to be the highest points of the peak (left, red crosses at the bottom of the figure) based on DEM analysis, and direct field measurement (right).

The final results were then compared with the heights published, among other places, on current and historical topographic and tourist maps as well as in various geoportals, such as the Geoportal website (https://www.geoportal.gov.pl/) and the Tourist Map website (TM, https://mapa-turystyczna.pl/) which is based on the OSM project (open street map), https://www.openstreetmap.org/. Other sources of information about the heights of peaks used in the research included published scientific and popular science sources, websites such as Wikipedia (https://wikipedia.org/), and historical sources (http://www.mapywig.org/).

\subsection{GNSS Measurement}

In most cases, the highest points of the peaks were clearly visible; in cases of doubt, we checked these points with a leveler, assessing differences between points which were believed to potentially be the highest. Then, we proceeded to GNSS measurement with a Leica GS16 receiver. We started with RTK using ASG-EUPOS corrections (http://www.asgeupos.pl/), and three 30-s measurements (final height was determined as the average of these measurements) with re-initialization as a precise (ambiguity fix) solution, ensuring accuracy to within $5 \mathrm{~cm}$. In cases when a precise RTK solution at the peak was not available, we conducted an hour-long static GNSS measurement with a 1-s measurement interval. As a reference, we adopted the nearest 2-4 ASG-EUPOS reference stations located closer than $100 \mathrm{~km}$. At many peaks, the GNSS measurement was carried out not at the highest point (due to large aerial obstacles), but in points with good visibility of the sky. In such cases, the height was transferred by geometrical leveling. The adopted measurement methodology allowed for accuracy on the order of single centimeters to be obtained, but we decided that for the final heights an accuracy to within $10 \mathrm{~cm}$ would be sufficient. This level of accuracy proved to be fully sufficient; in practice, the heights of mountains are usually published with a $1 \mathrm{~m}$ accuracy. In several cases, the difference between the published and measured heights of the highest peaks was less than $1 \mathrm{~m}$ (e.g., Łysica and Skała Agaty in the Świętokrzyskie Mountains). Static observations were post-processed in Leica Geo Office using IGS final orbits; then we determined normal heights using the height anomaly from the PL-geoid-2011 quasi-geoid model on the WGS-84 ellipsoid [15]. In the case of RTK measurements, normal heights were determined directly based on the abovementioned model. The published results are given according to the Kroonstadt 86 national height reference system, in this particular case PL-KRON86-NH [16]. In the territory of current-day Poland, the first leveling networks were established in the 1870s, when Poland did not exist as an independent state due to its occupation by foreign powers during the period known as the Partitions and its territory was divided between three countries: Austria, Prussia and Russia. The peaks listed in the CPM are located in areas which at that time belonged to two of these powers, Austria and Prussia. At that time, height systems in Austrian and Prussian lands were related to the level of two seas [17]: the Adriatic in the Austrian partition (as measured at Trieste) and the North Sea in the Prussian partition (as measured at Amsterdam). The differences used in this manuscript 
between Kroonstad-Trieste tide-gauges is $48 \mathrm{~cm}$ and Kroonstad-Amsterdam -14 cm, respectively [18]. After WWI, the reference point used in Poland was the tide-gauge in Amsterdam, while after WWII in the 1950s, there was a transition to a national height system referenced to the Kroonstad tide-gauge. Therefore, the differences arising from the use of different height reference systems could have had a significant impact only on the peaks located within the Austrian partition before 1918 (referenced to the Kroonstad-Trieste tide-gauge with a $48 \mathrm{~cm}$ difference). In the interwar years and after WWII up until the 1950s, these differences amounted to at most at a dozen centimeters.

\subsection{LIDAR Analyses}

The analysis of data seeking to identify the potentially highest point at the peak was based on data from a Polish project called ISOK [19] based on ALS (airborne laser scanning) measurements. The following products are available as part of the ISOK project:

- $\quad$ laser cloud points:

- $\quad$ density 4 pts $/ \mathrm{m}^{2}$ or 6 pts $/ \mathrm{m}^{2}$

- $\quad$ density $12 \mathrm{pts} / \mathrm{m}^{2}$ for the urban zones

- $\quad$ DTM GRID size $1.0 \mathrm{~m}$

- $\quad$ DTM GRID size $0.5 \mathrm{~m}$ (only for $12 \mathrm{pts} / \mathrm{m}^{2}$ )

The digital terrain model (DTM) obtained as part of the ISOK project was generated from LIDAR points as lying on the ground, as well as points in areas under water. This means that the process of filtering the remaining points (vegetation, buildings and other objects above ground level) was highly demanding. To fill in areas that were devoid of point cloud data, appropriate interpolation was performed. A numeric terrain model was developed in the PL-1992 coordinate system and the PL-KRON86-NH height system and was translated into WGS-84 geodetic coordinates (latitude and longitude. This was stored in two formats: ASCII (XYZ coordinates) and Esri GRID (ArcInfo ASCII GRID format). After obtaining the ALS and DTM data in accordance with the above-mentioned standards, analyses aimed at finding the highest points were carried out. According to research on the differences between different interpolation methods, the difference between ALS and DTM was smaller than the difference between GNSS measurement, influenced by various factors [19-25]. In the comparisons made between the values from the DEM model and the measurements from ASL for the designated points, the differences between the field research and the DTM analysis were puzzling. As a result of the analyses, a set of highest points was obtained for each peak. Results of the analysis were obtained for 52 points, and their mean absolute deviation between ALS and DTM was $0.04 \mathrm{~m}$, while the maximum difference was $0.22 \mathrm{~m}$ for the Ostra Mała peak (resulting from a few rocks located on the peak). For this reason, there was no indication whether the data was taken to the highest possible points at the peak from ALS or DTM (assumed resulting accuracy was $0.1 \mathrm{~m}$ ). In Tables 1 and 2, column $\mathrm{H}_{\mathrm{D}}$ contains height values obtained from DTM analysis, columns $\Delta \mathrm{H}_{\mathrm{A}-\mathrm{D}}$ (Table 1$)$ and column $\Delta \mathrm{H}_{\mathrm{N}-\mathrm{D}}$ (Table 2) contain values indicating the discrepancy between the measurement results and the result of the DTM analysis. The discrepancies between these values are quite significant, ranging from $-4.2 \mathrm{~m}$ (Śnieżnik, Table 1) to $+2.4 \mathrm{~m}$ (Okole, Table 2). In the case of negative differences, this is a fairly obvious problem arising from the qualification of low vegetation as ground points, or the classification of artificial embankments as soil elements. In the case of positive differences, the most likely factor affecting the result is the impact of dense stands of vegetation and soil cover at the top of the mountain [26-29]. 
Table 1. Results of the authors' own measurements and comparison with CPM, TM and DTM data.

\begin{tabular}{|c|c|c|c|c|c|c|c|c|c|c|}
\hline & Mountain Range & Highest Peak & $\begin{array}{l}\mathrm{H}_{\mathrm{A}} \\
(\mathrm{m})\end{array}$ & $\begin{array}{l}\mathrm{H}_{\mathrm{C}} \\
(\mathrm{m})\end{array}$ & $\begin{array}{c}\Delta \mathbf{H}_{\mathrm{A}-\mathrm{C}} \\
(\mathrm{m})\end{array}$ & $\begin{array}{l}\mathrm{H}_{\mathrm{T}} \\
(\mathrm{m})\end{array}$ & $\begin{array}{c}\Delta \mathbf{H}_{\mathrm{A}-\mathrm{T}} \\
(\mathrm{m})\end{array}$ & $\begin{array}{l}\mathrm{H}_{\mathrm{D}} \\
(\mathrm{m})\end{array}$ & $\begin{array}{c}\Delta \mathbf{H}_{\mathrm{A}-\mathrm{D}} \\
(\mathrm{m})\end{array}$ & $\begin{array}{l}\text { New } \\
\text { Peak }\end{array}$ \\
\hline 1 & Świętokrzyskie Mts & Eysica & 613.6 & 612 & 1.6 & 613 & 0.6 & 613.1 & 0.5 & $x$ \\
\hline 2 & Ślęża Massif & Ślęża & 717.8 & 718 & -0.2 & 718 & -0.2 & 717.3 & 0.5 & \\
\hline 3 & Kaczawskie Mts & Skopiec & 720.7 & 724 & -3.3 & 719 & 1.7 & 720.4 & 0.4 & $x$ \\
\hline 4 & Bardzkie Mts & Kłodzka Góra & 757.2 & 765 & -7.8 & 766 & -8.8 & 757.1 & 0.1 & $x$ \\
\hline 5 & Wałbrzyskie Mts & Chełmiec & 850.0 & 869 & -19.0 & 850 & 0.0 & 850.1 & -0.1 & $x$ \\
\hline 6 & Opawa Mts & Biskupia Kopa & 889.8 & 889 & 0.8 & 891 & -1.2 & 889.8 & 0.0 & \\
\hline 7 & Makowski Beskid Mts & Lubomir & 903.6 & 912 & -8.4 & 904 & -0.4 & 902.5 & 1.1 & \\
\hline 8 & Stołowe Mts & Szczeliniec Wielki & 921.7 & 919 & 2.7 & 919 & 2.7 & 921.6 & 0.1 & \\
\hline 9 & Mały Beskid Mts & Czupel & 930.7 & 934 & -3.3 & 933 & -2.3 & 931.1 & -0.3 & \\
\hline 10 & Kamienne Mts & Waligóra & 934.3 & 936 & 1.7 & 934 & 0.3 & 934.2 & 0.1 & \\
\hline 11 & Rudawy Janowickie Mts & Skalnik & 944.5 & 935 & 9.5 & 944 & 0.5 & 944.2 & 0.3 & $x$ \\
\hline 12 & Bystrzyckie Mts & Jagodna & 977.2 & 977 & 0.2 & 977 & 0.2 & 977.9 & -0.6 & $x$ \\
\hline 13 & Złote Mts & Kowadło & 988.0 & 989 & -1.0 & 989 & -1.0 & 989.7 & -1.7 & \\
\hline 14 & Low Beskid Mts & Lackowa & 997.9 & 997 & 0.9 & 997 & 0.9 & 996.8 & 1.1 & \\
\hline 15 & Sowie Mts & Wielka Sowa & 1015.7 & 1015 & 0.7 & 1015 & 0.7 & 1015.7 & -1.3 & \\
\hline 16 & Pieniny Mts & Wysoka & 1049.3 & 1050 & -0.7 & 1050 & -0.7 & 1049.3 & 0.0 & \\
\hline 17 & Orlickie Mts & Orlica & 1084.5 & 1084 & 0.5 & 1084 & 0.5 & 1084.3 & 0.2 & \\
\hline 18 & Bialskie Mts & Rudawiec & 1106.2 & 1112 & -5.8 & 1106 & 0.2 & 1106.9 & -0.7 & $\mathrm{x}$ \\
\hline 19 & Izerskie Mts & Wysoka Kopa & 1127.6 & 1126 & 1.6 & 1126 & 1.6 & 1127.3 & 0.3 & \\
\hline 20 & Wyspowy Beskid Mts & Mogielica & 1171.9 & 1170 & 1.9 & 1170 & 1.9 & 1170.4 & 1.6 & \\
\hline 21 & Silesian Beskid Mts & Skrzyczne & 1258.1 & 1257 & 1.1 & 1257 & 1.1 & 1256.8 & 1.3 & \\
\hline 22 & Sącz Beskid Mts & Radziejowa & 1262.1 & 1262 & 0.1 & 1262 & 0.1 & 1261.9 & 0.2 & \\
\hline 23 & Gorce Mts & Turbacz & 1309.9 & 1310 & -0.1 & 1310 & -0.1 & 1309.8 & 0.1 & \\
\hline 24 & Bieszczady Mts & Tarnica & 1346.1 & 1346 & 0.1 & 1346 & 0.1 & 1345.7 & 0.4 & \\
\hline 25 & Śnieżnik Massif & Śnieżnik & 1423.0 & 1425 & -2.0 & 1426 & -3.0 & 1427.2 & -4.2 & \\
\hline 26 & Karkonosze Mts & Śnieżka & 1603.2 & 1602 & 1.2 & 1603 & 0.2 & 1603.2 & 0.0 & \\
\hline 27 & Żywiec Beskid Mts & Babia Góra & 1723.6 & 1725 & -1.4 & 1723 & 0.6 & 1723.6 & 0.0 & \\
\hline 28 & Tatra Mts & Rysy & 2499.0 & 2499 & 0.0 & 2499 & 0.0 & 2499.4 & -0.4 & \\
\hline
\end{tabular}

Table 2. Heights and height differences between the official highest peaks and the newly established highest peaks.

\begin{tabular}{|c|c|c|c|c|c|c|c|c|}
\hline & Mountain & Highest Peak & $\begin{array}{l}\mathrm{H}_{\mathrm{O}} \\
(\mathrm{m})\end{array}$ & $\begin{array}{c}\text { New Highest } \\
\text { Peak }\end{array}$ & $\begin{array}{l}\mathrm{H}_{\mathrm{N}} \\
(\mathrm{m})\end{array}$ & $\begin{array}{c}\Delta \mathbf{H}_{\mathrm{N}-\mathrm{O}} \\
(\mathrm{m})\end{array}$ & $\begin{array}{l}\mathrm{H}_{\mathrm{D}} \\
(\mathrm{m})\end{array}$ & $\begin{array}{l}\Delta \mathrm{H}_{\mathrm{N}-\mathrm{D}} \\
(\mathrm{m})\end{array}$ \\
\hline 1 & Świętokrzyskie Mts & Eysica & 613.6 & Skała Agaty & 614.0 & 0.4 & 613.4 & 0.6 \\
\hline 2 & Kaczawskie Mts & Skopiec & 720.7 & Okole & 725.3 & 4.0 & 722.9 & 1.8 \\
\hline 3 & Bardzkie Mts & Kłodzka Góra & 757.2 & Szeroka Góra & 766.3 & 9.1 & 766.0 & 0.3 \\
\hline 4 & Wałbrzyskie Mts & Chełmiec & 850 & Borowa & 853.4 & 3.4 & 853.4 & 0.0 \\
\hline 5 & Rudawy Janowickie Mts & Skalnik & 944.5 & Ostra Mała & 944.8 & 0.3 & 944.4 & 0.4 \\
\hline 6 & Bystrzyckie Mts & Jagodna & 977.2 & Jagodna Północna & 984.5 & 7.3 & 985.1 & -0.6 \\
\hline 7 & Bialskie Mts & Rudawiec & 1106.2 & Postawna & 1115.5 & 9.3 & 1115.9 & -0.4 \\
\hline
\end{tabular}

\section{Results}

Table 1 summarizes all 28 CPM summits, including the heights obtained from the authors' own measurements $\left(\mathrm{H}_{\mathrm{A}}\right)$, from the CPM $\left(\mathrm{H}_{\mathrm{C}}\right)$, TM websites $\left(\mathrm{H}_{\mathrm{T}}\right)$ and DTM data $\left(\mathrm{H}_{\mathrm{D}}\right)$, together with the differences between our results $(\Delta \mathrm{H})$. In addition, the last column contains the names of peaks which as a result of this study proved to be the highest in the given range and should be officially treated as such.

The results show differences of up to $19.0 \mathrm{~m}$ when compared to data from the CMP (14 height differences less than $1 \mathrm{~m}$ ) and up to $8.8 \mathrm{~m}$ in the case of TM (18 differences less than $1 \mathrm{~m}$ ). This indicates the need for the correction of the height of almost all the analyzed peaks; only four CPM peak heights (five in the case of TM) fit within the $10 \mathrm{~cm}$ measurement accuracy adopted for the purposes of this study. DTM data are the most accurate (21 differences less than $1 \mathrm{~m}$ ), but cannot be used as a method of measuring the heights of peaks, due to low reliability. This method may be used in a supporting role for GNSS measurements. Table 2 shows the actual measured heights and differences from currently accepted heights for seven summits which are higher than their officially recorded heights and which should be treated officially as the highest peak in each mountain range.

Interestingly, in the case of only two mountain ranges are the differences less than $1 \mathrm{~m}$ (Świętkorzyskie Mts and Rudawy Janowickie Mts). In the case of the remaining heights, these differences range from $3.4 \mathrm{~m}$ to $9.3 \mathrm{~m}$. The differences between the measured heights and heights determined from DTM analysis in most cases did not exceed $1 \mathrm{~m}$. The only peak for which this value 
exceeded $1 \mathrm{~m}$ is the Okole peak (Kaczawskie Mts) for which the difference was $2.4 \mathrm{~m}$. This results not from the inaccuracy of measurement, but from incorrectly adopted peaks which were until now considered to be the highest.

\section{Discussion}

To the best of the authors' knowledge, no study such as the present one has been conducted so far. Modern measurement techniques have been used only for the determination of the height of individual mountain peaks, as was presented in the Introduction section. This study successfully demonstrates the necessity for verification of the heights of mountain peaks. These results indicate that the actual heights of almost every mountain range analyzed in this study were incorrect. The measurement accuracy was $10 \mathrm{~cm}$, and taking into account this level of accuracy only four (14\%) and five (18\%) heights from the CPM and TM databases respectively were consistent with the new measurements. Due to the fact that mountain peaks generally do not have clearly defined points on the top, heights are given with an accuracy of $1 \mathrm{~m}$. Taking into account this level of accuracy, the number of consistent heights increased to six (21\%) and 11 (39\%) for the CPM and TM databases respectively. However, in many cases, the differences exceed the measurement accuracy significantly and reach up to several meters, such as in the case of Kłodzka Góra $(7.8 \mathrm{~m}$ and $8.8 \mathrm{~m}$ for the CPM and TM databases respectively), Czupel (3.3 $\mathrm{m}$ and $2.3 \mathrm{~m}$ ) or Szczeliniec Wielki $(2.7 \mathrm{~m}$ and $2.7 \mathrm{~m})$.

It is the belief of the authors that the presented measurements are pioneering. Peak measurements usually refer to a single peak, e.g., the highest peak in Europe. We believe that results taking into account only ALS or DEM data for all peaks are not a satisfactory way to obtain peak height data without verification. It is necessary to understand the nature of the vegetation, buildings or residue from human activities that cover the summit. One could venture to say that the automatic transfer of peak heights from ALS or DEM data will be affected by random errors that the statistical apparatus cannot detect. According to the authors, the use of artificial intelligence may have an interesting application in this area. To this end, further measurements are needed to build an appropriate knowledge base.

This study was limited by time, human and financial resources, and thus it took almost 6 months to conduct height measurements of 40 peaks. However, this project showed the necessity of measurement and verification of all mountain peaks, especially those for which there are different heights given in existing source materials. Again, to our knowledge, no studies have questioned the heights of the highest peaks of individual mountain ranges. Our study covers Polish mountain mesoregions and shows that $25 \%$ of mountain ranges that are officially considered as the highest peaks in their ranges are in fact not the highest peaks. Differences in measured versus documented heights of almost all of them are more than $3 \mathrm{~m}$ and can even be up to $9.3 \mathrm{~m}$ (Bialskie Mts). It is to be expected that similar measurements of other, smaller (micro-regions) mountain ranges in Poland or of other mountain ranges in the world will show similar results. We hope that the conclusions presented in this paper will allow us to update the seven highest peaks of the Polish mountain mesoregions to those that are in fact the highest. In addition, this article will be useful as a reference for publication of correct values of the heights of the studied summits in future published materials, books, the Internet, etc.

\section{Conclusions}

This paper presents the main results of a project, which aimed to establish the correct measurement and verification of the highest peaks of all Polish mountain ranges using precise GNSS measurements. Different techniques such as LIDAR, InSAR or another non-invasive measurement would not have provided such precise, and more importantly reliable, heights. The differences between the measurements and DTM show that only 50\% of the results from DTM are consistent with the measurements. In order to further analyze the reasons for these differences, individual peaks should be analyzed. For example, the difference at the summit of Śnieżnik $\left(\mathrm{H}_{\mathrm{A}}=1423.0 \mathrm{~m}\right.$ above sea level $\mathrm{H}_{\mathrm{D}}=1427.2 \mathrm{~m}$ above sea level, i.e., a difference of $4.2 \mathrm{~m}$ ) results from the acceptance of the ruins of a building (rubble) as natural ground. On the other hand, for the Mogielica peak (the peak is forested 
with an observation tower) this difference is $1.6 \mathrm{~m}$ and results from the filtering and classification of ALS points. Therefore, the conclusion that comes to mind is that ALS values cannot be uncritically accepted as unambiguous and exact height values for peaks.

The results showed differences between officially known and adopted heights of more than a dozen meters, with an average of several meters. These differences confirm the need to verify all the highest or most popular mountain peaks for individual mountain ranges using satellite techniques, because currently listed heights may not be valid. In addition to the alteration of the height of individual peaks in the official lists, this revision also requires a change in the peaks considered to be the highest for some mountain ranges (here $25 \%, 7$ of 28 ) and this paper may provide the basis for an official change. Moreover, measurements of this type may also have an impact on mountain hiking habits, making new hiking routes the most attractive in a given range.

Author Contributions: Conceptualization, K.K. and K.M.; methodology, K.K. and K.M.; software, K.K. and K.M.; validation, K.K. and K.M.; formal analysis, K.K. and K.M.; investigation, K.K. and K.M.; resources, K.K. and K.M.; data curation, K.K. and K.M.; writing-original draft preparation, K.K. and K.M.; writing-review and editing, K.K. and K.M.; visualization, K.K. and K.M.; supervision, K.K. and K.M.; project administration, K.K. and K.M.; funding acquisition, K.K. All authors have read and agreed to the published version of the manuscript.

Funding: This research was funded by 'Setka w Koronie. Korona Gór Polski na 100-lecie AGH' project (http: //koronagor.agh.edu.pl/).

Acknowledgments: This paper was created as part of statutory research 16.16.150.545.

Conflicts of Interest: The authors declare no conflict of interest.

\section{References}

1. Lewandowski, W.; Więckowski, M. Korona Gór Polski. Poznaj Swój Kraj 1997, 422, 17.

2. Kudrys, J.; Buśko, M.; Kozioł, K.; Maciuk, K. Determination of the normal height of Chornohora summits by a precise modern measurement techniques. Maejo Int. J. Sci. Technol. 2020, 14, 2.

3. Fenna, D. Jednostki Miar; Świat Książki: Warszawa, Polska, 2004; p. 328.

4. Ward, M. The height of Mount Everest. Alp. J. 1995, 100, 30-33.

5. Junyong, C.; Yanping, Z.; Janli, Y.; Chunxi, G.; Peng, Z. Height Determination of Qomolangma Feng (MT. Everest) in 2005. Surv. Rev. 2010, 42, 122-131. [CrossRef]

6. De Graaff-Hunter, J. De Various Determinations over a Century of the Height of Mount Everest. Geogr. J. 1955, 121, 21-26. [CrossRef]

7. De Beer, G. The history of the altimetry of Mont Blanc. Ann. Sci. 1956, 12, 3-29. [CrossRef]

8. Poretti, G.G. America's highest peak now measures 6962 metres! Report. Mag. Leica Geosystems 1999, 47, 28-29.

9. Saburi, J.; Angelakis, N.; Jaeger, R.; Illner, M.; Jackson, P.; Pugh, K.T. Height measurement of Kilimanjaro. Surv. Rev. 2000, 35, 552-562. [CrossRef]

10. TeamKILI2008. Precise Determination of the Orthometric Height of Mt Kilimanjaro. In FIG Working Week 2009; FIG: Eilat, Israel, 2009; p. 11.

11. Makowska, A. Dynamika Tatr Wyznaczana Metodami Geodezyjnymi; Instytut Geodezji I Kartografii: Warszawa, Poland, 2003; No. 6.

12. Chen, W.; Li, X.; Wang, Y.; Chen, G.; Liu, S. Forested landslide detection using LiDAR data and the random forest algorithm: A case study of the Three Gorges, China. Remote Sens. Environ. 2014, 152, 291-301. [CrossRef]

13. Puniach, E.; Mamczarz, K.; Niewiem, W. Assessment of the Possibility of Using Unmanned Aerial Vehicles (UAVs) for the Documentation of Hiking Trails in Alpine Areas. Sensors 2018, 18, 81.

14. Hejmanowski, R.; Malinowska, A.A.; Witkowski, W.T.; Guzy, A. An Analysis Applying InSAR of Subsidence Caused by Nearby Mining-Induced Earthquakes. Geosciences 2019, 9, 490. [CrossRef]

15. Kadaj, R. Algorytm opracowania modelu PL-geoid-2011. In Realizacja Osnów Geodezyjnych a Problemy Geodynamiki; Politechnika Warszawska: Grybów, Poland, 2012; p. 26.

16. Ministrów, R. Rozporządzenie Rady Ministrów z Dnia 15 Października 2012 r. w Sprawie Państwowego Systemu Odniesień Przestrzennych; Kancelaria Prezesa Rady Ministrów: Warszawa, Poland, 2012; p. 8. 
17. Balasubramanian, N. Definition and Realization of a Global Vertical Datum; Scientific Report, No.1; The Ohio State University, Department of Geodetic Science and Surveying: Columbus, OH, USA, 1994.

18. Wiśniewski, B.; Giza, A.; Wolski, T. Adjustment of the European Vertical Reference System for the representation of the Baltic Sea water surface topography. Zesz. Nauk. Akad. Morska w Szczecinie 2014, 38, 106-117.

19. Stereńczak, K.; Ciesielski, M.; Balazy, R.; Zawiła-Niedźwiecki, T. Comparison of various algorithms for DTM interpolation from LIDAR data in dense mountain forests. Eur. J. Remote Sens. 2016, 49, 599-621. [CrossRef]

20. Graham, A.N.V.; Coops, N.C.; Tompalski, P.; Plowright, A.; Wilcox, M. Effect of ground surface interpolation methods on the accuracy of forest attribute modelling using unmanned aerial systems-based digital aerial photogrammetry. Int. J. Remote Sens. 2020, 41, 3287-3306. [CrossRef]

21. Shamsoddini, A.; Turner, R.; Trinder, J.C. Improving lidar-based forest structure mapping with crown-level pit removal. J. Spat. Sci. 2013, 58, 29-51. [CrossRef]

22. Godone, D.; Garnero, G. The role of morphometric parameters in Digital Terrain Models interpolation accuracy: A case study. Eur. J. Remote Sens. 2013, 46, 198-214. [CrossRef]

23. Chow, T.E.; Hodgson, M.E. Effects of lidar post-spacing and DEM resolution to mean slope estimation. Int. J. Geogr. Inf. Sci. 2009, 23, 1277-1295. [CrossRef]

24. Lloyd, C.D.; Atkinson, P.M. Deriving ground surface digital elevation models from LiDAR data with geostatistics. Int. J. Geogr. Inf. Sci. 2006, 20, 535-563. [CrossRef]

25. Lloyd, C.D.; Atkinson, P.M. Deriving DSMs from LiDAR data with kriging. Int. J. Remote Sens. 2002, 23, 2519-2524. [CrossRef]

26. Guo, Q.; Su, Y.; Hu, T.; Zhao, X.; Wu, F.; Li, Y.; Liu, J.; Chen, L.; Xu, G.; Lin, G.; et al. An integrated UAV-borne lidar system for 3D habitat mapping in three forest ecosystems across China. Int. J. Remote Sens. 2017, 38, 2954-2972. [CrossRef]

27. Su, Y.; Guo, Q.; Collins, B.M.; Fry, D.L.; Hu, T.; Kelly, M. Forest fuel treatment detection using multi-temporal airborne lidar data and high-resolution aerial imagery: A case study in the Sierra Nevada Mountains, California. Int. J. Remote Sens. 2016, 37, 3322-3345. [CrossRef]

28. Su, Y.; Guo, Q.; Fry, D.L.; Collins, B.M.; Kelly, M.; Flanagan, J.P.; Battles, J.J. A Vegetation Mapping Strategy for Conifer Forests by Combining Airborne LiDAR Data and Aerial Imagery. Can. J. Remote Sens. 2016, 42, 1-15. [CrossRef]

29. Bigdeli, B.; Gomroki, M.; Pahlavani, P. Generation of digital terrain model for forest areas using a new particle swarm optimization on LiDAR data. Surv. Rev. 2020, 52, 115-125. [CrossRef]

(C) 2020 by the authors. Licensee MDPI, Basel, Switzerland. This article is an open access article distributed under the terms and conditions of the Creative Commons Attribution (CC BY) license (http://creativecommons.org/licenses/by/4.0/). 